\title{
Quantitative changes in soil properties and plant uptake of metals on municipal solid waste dumpsite in Nigeria
}

\author{
O. T. Ogunmodede*, E. Adewole, A. A. Ojo. \\ Department of chemical sciences, Afe Babalola University, Ado Ekiti, Nigeria. \\ *E-mail address: taiwokehindelolade@gmail.com
}

Keywords: Geo-accumulation index, Pollution load index, Water quality index, Enrichment factor, Translocation factor.

\begin{abstract}
In this work concentrations of $\mathrm{Cd}, \mathrm{Pb}, \mathrm{Cr}, \mathrm{Fe}, \mathrm{Co}, \mathrm{Ni}, \mathrm{Cu}, \mathrm{Zn}$ and $\mathrm{Mn}$ were determined in soils and plants from refuse dumpsites in Ado Ekiti, Nigeria. The refuse dump soils were evaluation using contamination/pollution factor(C/P), Enrichment factor (EF), Index of Geoaccumulation (Igeo) and Pollution load index were calculated. The observation suggests high $\mathrm{C} / \mathrm{P}$ values of the dump soil are polluted by $\mathrm{Cd}, \mathrm{Cr}$ and $\mathrm{Ni}$ acts as a sink for heavy metals contributed from anthropogenic sources in the study area. C/P data, EF, PLI and (Igeo) indicated that these heavy metals originate from anthropogenic sources. Fe and Ni loads in plants from the refuse dump soils pronounced maximum concentration than Nigeria guideline. Transfer ratios for $\mathrm{Cd}, \mathrm{Co}, \mathrm{Cu}, \mathrm{Zn}, \mathrm{Pb}$ and $\mathrm{Fe}$ of plants from the control soils were higher than those from the refuse dump soils,
\end{abstract}

\section{INTRDUCTION}

Soil is a vital resource for sustaining basic human needs, a quality food supply and a livable environment. It serves as a sink and recycling factory for both liquid and solid wastes known as dumpsite [1]. Dumpsites, especially in most third world countries, comprise of a higher proportion $(50-90 \%)$ of organic materials [2]; however, a considerable proportions of plastic, paper, metal rubbish and batteries which are known to be sources of metals which may be hazardous to man and his environment are also present [3]. These metals are not biodegradable and have toxic effects on living organisms at certain level of concentration. Exposure of man to such metals may cause blood and bone disorders, kidney damage and decreased mental capacity and neurological damage [4]. Crops absorb whatever is present in the soil medium and therefore these hazardous metals are also absorbed and become bio-accumulated in the roots, stems, fruits, grains and leaves of the crops [5], which may finally be transferred to man in the food chain. Most edible crops are indiscriminate in their extraction of nutrients from the soil and thus will extract the non-desirable heavy metals alongside the required essential nutrients. The present study was carried out to examine the effects of municipal solid waste on soil physicochemical properties and identify the possible pathway for the transfer of heavy metals from these sites into the food chain.

\section{MATERIALS AND METHODS}

\subsection{Study area: Ado Ekiti}

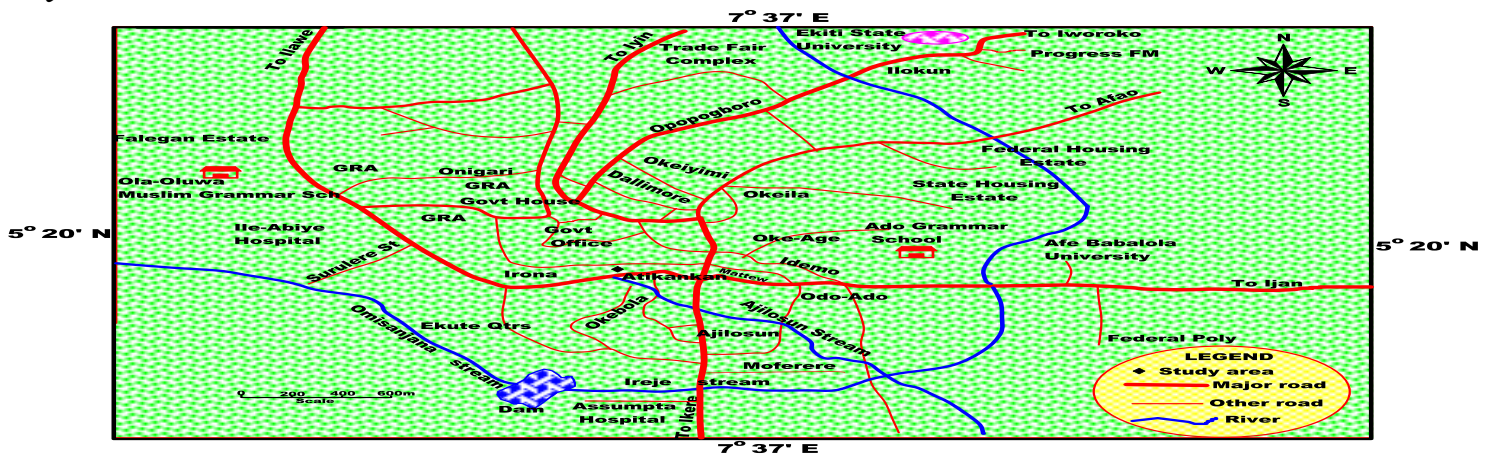

Fig.1 The study area within Ado Ekiti showing sampling location Atinkankan 
Ado Ekiti is the capital city of Ekiti State, south western Nigeria. The city is at the centre on latitude $7.37^{\circ} \mathrm{N}$ and longitude $5.15^{\circ} \mathrm{E}$, situated in a valley $250 \mathrm{~m}$ above sea level. The population in the city is unevenly distributed such that commercial, industrial and agricultural, recreational and administrative, auto-mechanic workshops and residential areas are scattered all over the city and these serve as point sources of heavy metals [6]. One sampling station was identified within Ado Ekiti town namely: Atinkankan, an area well known for repairing and maintaining automobiles, centre dumpsite for market traders with a large clientele. The grounds of the Afe Babalola University were used as a control site for this station. This site was chosen for investigation, being the major city dumpsite and for its sheer size, daily and frequent usage, and because of its long-term waste deposition in the Ado Ekiti Metropolitan Area.

\subsection{Sample collection and sample treatment}

Surface soils are the first locus of input of metals where they tend to accumulate on a relatively long term basis [7]. These pollutants normally contaminate the upper layer of the soil at a depth $(0-40)$ $\mathrm{cm}$ [8]. This implies that, high concentration of these pollutants could be present at this depth if assessed. Given the foregoing, 9 surface soil samples were collected randomly from of the designated dumpsites at a depth of $0-15 \mathrm{~cm}$. Control samples were collected from Afe Babalola University farm where neither car repairs, industrial nor commercial activities are carried out. The samples were placed in labeled polythene bags and transported to the laboratory. All soil Samples were subsequently air-dried to constant weight to avoid microbial degradation [9]. They were homogenized, made lump free by gently crushing repeatedly using an acid pre-washed mortar and pestle, and passed through a $2 \mathrm{~mm}$ plastic sieve prior to analysis. Thus, a total of 20 surface soil samples were randomly collected from the study areas.

\subsection{Determination of physiochemical properties of the soils}

The physiochemical properties of the soil samples were determined using routine methods as described by [10] and [11]

\subsection{Heavy metal analysis}

One gram of the dried fine soil sample was weighed and transferred into an acid washed, round bottom flask containing $10 \mathrm{~cm}^{3}$ concentrated nitric acid. The mixture was slowly evaporated over a period of 1 hour on a hot plate. Each of the solid residues obtained was digested with a 3:1 concentrated $\mathrm{HNO}_{3}$ and $\mathrm{HClO}_{4}$ mixture for 10minutes at room temperature before heating on a hot plate. The digested mixture was placed on a hot plate and heated intermittently to ensure a steady temperature of $150^{\circ} \mathrm{C}$ over 5 hours until the fumes of $\mathrm{HClO}_{4}$ were completely evaporated [12]. The mixture was allowed to cool to room temperature and then filtered using Whatman No.1 filter paper into a $50 \mathrm{~cm} 3$ volumetric flask and made up to the standard mark with deionized water after rinsing the reacting vessels, to recover any residual metal. The filtrate was then stored in pre-cleaned polyethylene storage bottles ready for analysis.

Blank determinations were carried out simultaneously with the samples concentration of each metal in the sample solution was measured against those of serially diluted with standard solutions containing each metal. Cadmium, lead, copper, chromium, zinc, nickel and iron were determined in all standard solutions, samples and blank solutions by Buck scientific model 200A/240 Atomic Absorption spectrophotometer with Air - acetylene flame at Centre Laboratory University of Ibadan.

\subsection{Heavy metals in plant determination:}

Five edible plant samples - cocoyam tuber and leaves (Xanthosoma mafaffa), cassava tuber and leaves (Manihot esculenta),pawpaw (carica papaya), plantain (Musa sapientum) and water leaves (Talinum triangulare) - grown within the vicinity of the refuse dump site were randomly collected with a stainless steel trowel and knife. Plant samples of the same species were also collected as 
control from the unpolluted site chosen as control. The dried sample was pulverized using an agate pestle and mortar and kept in polythene bags. Dry powdered crop samples were digested with a mixture of $60 \% \mathrm{HClO}_{4}$, concentrated $\mathrm{HNO}_{3}$ and $\mathrm{H}_{2} \mathrm{SO}_{4}$. Blanks were prepared to check for background contamination by the reagents used as described by [13]. The digested samples were analyzed for heavy metals using Buck scientific model 200A/240 Atomic Absorption spectrophotometer with Air - acetylene flame at Centre Laboratory University of Ibadan, Nigeria.

\subsection{Quality assurance}

Quality control test was conducted on soil in order to evaluate the experimental procedures and efficiency of atomic absorption spectrophotometer. This was done by spiking the pre-digested soil with multi-elemental metal standard solution [14]

\subsection{Data Evaluation}

2.7.1 Geoaccumulation index $\left(\mathbf{I}_{\mathbf{G E O}}\right)$ : Pollution levels of heavy metals in Ado Ekiti could be characterized by the geo-accumulation index (Igeo) [15]. This can be defined as the following equation:

$\operatorname{Igeo}=\ln \{\mathrm{Cn} / 1.5 \mathrm{Bn}\}$.

where $\mathrm{Cn}$ is the measured content of individual heavy metal in Ado Ekiti,

Bn: the background or pristine value of individual heavy metal. The control samples were taken to represent the background and1.5 is the constant factor introduced to analyze natural fluctuations in the contents of a given substance in the environment and very small anthropogenic influences. There are seven classes of the geoaccumulation index are stated in table1,

Table 1: Seven Descriptive classes of Geoaccumulation index

\begin{tabular}{|l|l|l|}
\hline $\mathbf{s} / \mathbf{n}$ & Class & Description \\
\hline 1 & $<0$ & practically uncontaminated \\
\hline 2 & $0-1$ & $\begin{array}{l}\text { uncontaminated to } \\
\text { slightly contaminated }\end{array}$ \\
\hline 3 & $1-2$ & moderately contaminated \\
\hline 4 & $2-3$ & $\begin{array}{l}\text { moderately to highly } \\
\text { contaminated }\end{array}$ \\
\hline 5 & $3-4$ & highly contaminated \\
\hline 6 & $4-5$ & $\begin{array}{l}\text { highly to very highly } \\
\text { contaminated }\end{array}$ \\
\hline 7 & $>5$ & very highly/strongly contaminated \\
\hline
\end{tabular}

\subsubsection{Contamination/pollution index (C/P)}

This was calculated by employing previously used method [16] with the following modifications/definitions:

$\mathrm{C} / \mathrm{P}=$ Concentration of the metal in soil/Target value

The target value was obtained by using the standard formulated by the Department of Petroleum Resources of Nigeria (DPR), for maximum allowed concentration of heavy metals in soils. 
Table 2: Standard formulated by the Department of Petroleum Resources of Nigeria (DPR), for maximum allowed concentration of heavy metals in soils.

\begin{tabular}{|l|l|l|}
\hline $\mathbf{s} / \mathbf{n}$ & Heavy metal in soil & $\begin{array}{l}\text { Maximum allowed } \\
\text { concentration } \\
\text { (ppm) }\end{array}$ \\
\hline 1 & $\mathrm{Cd}$ & 0.8 \\
\hline 2 & $\mathrm{Cr}$ & 100.0 \\
\hline 3 & $\mathrm{~Pb}$ & 85.0 \\
\hline 4 & $\mathrm{Ni}$ & 35.0 \\
\hline 5 & $\mathrm{Zn}$ & 140.0 \\
\hline 6 & $\mathrm{Co}$ & 20.0 \\
\hline 7 & $\mathrm{Hg}$ & 0.30 \\
\hline 8 & $\mathrm{Cu}$ & 36.0 \\
\hline 9 & $\mathrm{Mn}$ & 476.0 \\
\hline 10 & $\mathrm{Fe}$ & 5000.0 \\
\hline
\end{tabular}

The significance of interval of contamination/pollution index [17], are given below.

Table 3: The significance of interval of contamination/pollution index

\begin{tabular}{|l|l|l|}
\hline $\mathbf{s} / \mathbf{n}$ & class & Significance \\
\hline 1 & $<.1$ & Very slight contamination \\
\hline 2 & $0.10-0.25$ & slightly contamination \\
\hline 3 & $0.26-0.5$ & Moderate contamination \\
\hline 4 & $0.51-0.75$ & Severe contamination \\
\hline 5 & $0.76-1.00$ & Very severe contamination \\
\hline 6 & $1.10-2.0$ & Slight pollution \\
\hline 7 & $2.1-4.0$ & Moderate pollution \\
\hline 8 & $4.1-9.0$ & severe pollution \\
\hline 9 & $9.1-16.0$ & Very severe pollution \\
\hline 10 & $>16.0$ & Excessive pollution \\
\hline
\end{tabular}

The values less than 1 define contamination range while greater than 1 defines pollution range.

2.7.3 Enrichment factor (EF): By following established method [18], EF was employed to assess the degree of contamination and to understand the distribution of the elements of anthropogenic origin from sites by individual elements in sediments. Fe was chosen as the normalizing element when determining EF-values, since in wetlands it is mainly supplied from sediments and is one of the widely used reference element [19]. Other widely used metal elements are Al, Mn[20] The EF is defined as follows:

Enrichment factor $=(\mathrm{Cn} / \mathrm{Fe})$ sample $/(\mathrm{Cn} / \mathrm{Fe})$ background,

Where, $\mathrm{Cn}$ is the concentration of element " $\mathrm{n}$ ". The background value is that of control sample. An element qualifies as a reference one if it is of low occurrence variability and is present in the environment in trace amounts [19]. Elements which are naturally derived have an EF value of nearly unity, while elements of anthropogenic origin have EF values of several orders of magnitude. Six categories are recognized [21], as stated bellow: 
Table 4: Descriptive classes of Enrichment factor index

\begin{tabular}{|l|l|l|}
\hline $\mathbf{s} / \mathbf{n}$ & Class & Description \\
\hline 1 & $<1$ & background concentration \\
\hline 2 & $1-2$ & $\begin{array}{l}\text { depletion to minimal } \\
\text { enrichment }\end{array}$ \\
\hline 3 & $2-5$ & moderate enrichment \\
\hline 4 & $5-20$ & significant enrichment \\
\hline 5 & $20-40$ & very high enrichment \\
\hline 6 & $>40$ & extremely high enrichment \\
\hline
\end{tabular}

2.7.4 Pollution load index (PLI): Pollution load index for each site was evaluated as indicated by [22].

Pollution load index $=(\mathrm{CF} 1 * \mathrm{CF} 2 * \ldots . . * \mathrm{CFn})^{1 / \mathrm{n}}$

Where, $\mathrm{n}$ is the number of metals (six in the present study). The PLI value $>1$ is polluted whereas PLI value $<1$ indicates no pollution.

2.7.5 Quantification of soil contamination (QoC) The third approach using the quantification of anthropogenic concentration of metal employs the concentration in the control samples to represent the lithogenic metal. This is calculated as

Quantification of anthropogenic metal Anthropogenic metal $=\frac{X-X c}{X} \times 100$

Where $\mathrm{X}=$ average concentration of the metal in the soil under investigation, and $\mathrm{Xc}=$ average concentration of the metal in the control samples [23]. All the indices were employed to assess the impact of the auto mechanic works on the surrounding soils.

\section{RESULTS}

Table 5 Physicochemical properties of soil close to Atikankan dumpsite.

\begin{tabular}{lcccc}
\hline \multicolumn{1}{c}{ Parameter } & $\begin{array}{c}\text { Distance 0 } \\
\text { Depth 0- 15cm }\end{array}$ & $\begin{array}{c}\text { Distance 10m } \\
\text { Depth 0 -15cm }\end{array}$ & $\begin{array}{c}\text { Distance 20m } \\
\text { Depth 0- 15cm }\end{array}$ & $\begin{array}{c}\text { Control } \\
\text { 0- 15cm }\end{array}$ \\
\hline pH & $7.26 \pm 0.03$ & $7.26 \pm 0.04$ & $7.03 \pm 0.01$ & $6.60 \pm 0.04$ \\
Sand \% & $46.32 \pm 0.11$ & $43.13 \pm 0.06$ & $41.62 \pm 0.04$ & $52.01 \pm 0.01$ \\
Silt \% & $15.10 \pm 0.04$ & $15.13 \pm 0.03$ & $14.96 \pm 0.03$ & $14.43 \pm 0.01$ \\
Clay \% & $44.07 \pm 0.09$ & $43.52 \pm 0.13$ & $43.61 \pm 0.04$ & $30.11 \pm 0.03$ \\
OC \% & $2.80 \pm 0.03$ & $2.55 \pm 0.04$ & $2.28 \pm 0.02$ & $0.39 \pm 0.03$ \\
Om \% & $4.83 \pm 0.02$ & $4.40 \pm 0.02$ & $3.91 \pm 0.01$ & $0.67 \pm 0.01$ \\
EB (cmol/kg) & $6.02 \pm 0.01$ & $5.73 \pm 0.03$ & $5.78 \pm 0.02$ & $1.43 \pm 0.01$ \\
EA (cmol/kg) & $0.68 \pm 0.02$ & $0.62 \pm 0.02$ & $0.59 \pm 0.03$ & $0.47 \pm 0.01$ \\
ECEC & $6.70 \pm 0.03$ & $6.35 \pm 0.02$ & $6.37 \pm 0.02$ & $1.90 \pm 0.02$ \\
\hline
\end{tabular}

Table6 Metal concentration in soil close to Atikankan dumpsite.

\begin{tabular}{lcccc}
\hline \multicolumn{1}{c}{ Parameter } & $\begin{array}{c}\text { Distance 0 } \\
\text { Depth 0- 15cm }\end{array}$ & $\begin{array}{c}\text { Distance 10m } \\
\text { Depth 0 -15cm }\end{array}$ & $\begin{array}{c}\text { Distance 20m } \\
\text { Depth 0- 15cm }\end{array}$ & $\begin{array}{c}\text { Control } \\
\text { 0- 15cm }\end{array}$ \\
\hline $\mathrm{Pb}(\mathrm{mg} / \mathrm{kg})$ & $182.05 \pm 1.25$ & $144.85 \pm 2.20$ & $136.91 \pm 1.13$ & $23.68 \pm 0.04$ \\
$\mathrm{Ni}(\mathrm{mg} / \mathrm{kg})$ & $118.35 \pm 0.23$ & $101.22 \pm 0.12$ & $89.76 \pm 0.06$ & $20.84 \pm 0.02$ \\
$\mathrm{Cr}(\mathrm{mg} / \mathrm{kg})$ & $115.86 \pm 0.08$ & $115.22 \pm 0.14$ & $98.11 \pm 0.03$ & $12.10 \pm 0.02$ \\
$\mathrm{Cd}(\mathrm{mg} / \mathrm{kg})$ & $11.62 \pm 0.02$ & $11.02 \pm 0.02$ & $10.13 \pm 0.01$ & $0.16 \pm 0.01$ \\
$\mathrm{Cu}(\mathrm{mg} / \mathrm{kg})$ & $550.92 \pm 1.12$ & $521.30 \pm 1.00$ & $426.25 \pm 0.32$ & $315.02 \pm 0.02$ \\
$\mathrm{Fe}(\mathrm{mg} / \mathrm{kg})$ & $4387.52 \pm 3.12$ & $4263.23 \pm 2.51$ & $3981.51 \pm 2.23$ & $1892.43 \pm 1.33$ \\
$\mathrm{Zn}(\mathrm{mg} / \mathrm{kg})$ & $311.06 \pm 0.12$ & $280.32 \pm 0.10$ & $251.76 \pm 0.16$ & $99.12 \pm 0.08$ \\
$\mathrm{Mn}(\mathrm{mg} / \mathrm{kg})$ & $221.36 \pm 0.04$ & $202.41 \pm 0.11$ & $181.14 \pm 0.02$ & $87.42 \pm 0.04$ \\
\hline
\end{tabular}


Table 7 Geoaccumulation index of soil close to Atikankan dumpsite.

\begin{tabular}{lcccc}
\hline Parameter & $\begin{array}{c}\text { Distance 0 } \\
\text { Depth 0-30cm }\end{array}$ & $\begin{array}{c}\text { Distance 10m } \\
\text { Depth 0 -30cm }\end{array}$ & $\begin{array}{c}\text { Distance 20m } \\
\text { Depth 0-30cm }\end{array}$ & $\begin{array}{c}\text { mean } \\
\text { Igeo }\end{array}$ \\
\hline $\mathrm{Pb}$ & 1.63 & 1.41 & 1.35 & 1.46 \\
$\mathrm{Ni}$ & 1.33 & 1.18 & 1.06 & 1.37 \\
$\mathrm{Cr}$ & 1.85 & 1.85 & 1.69 & 1.80 \\
$\mathrm{Cd}$ & 3.88 & 3.83 & 3.74 & 3.81 \\
$\mathrm{Cu}$ & 0.15 & 0.10 & -0.10 & 0.05 \\
$\mathrm{Fe}$ & 0.44 & 0.41 & 0.34 & 0.40 \\
$\mathrm{Zn}$ & 0.74 & 0.63 & 0.53 & 0.63 \\
$\mathrm{Mn}$ & 0.52 & 0.43 & 0.32 & 0.42 \\
\hline
\end{tabular}

Table 8 Contamination /pollution index of soil close to Atikankan dumpsite.

\begin{tabular}{lcccc}
\hline Parameter & $\begin{array}{c}\text { Distance 0 } \\
\text { Depth 0-15cm }\end{array}$ & $\begin{array}{c}\text { Distance 10m } \\
\text { Depth 0 -15cm }\end{array}$ & $\begin{array}{c}\text { Distance 20m } \\
\text { Depth 0-15cm }\end{array}$ & $\begin{array}{c}\text { mean } \\
\text { C/P }\end{array}$ \\
\hline $\mathrm{Pb}$ & 2.14 & 1.70 & 1.61 & 1.82 \\
$\mathrm{Ni}$ & 3.38 & 2.89 & 2.57 & 2.95 \\
$\mathrm{Cr}$ & 1.16 & 1.15 & 0.98 & 1.10 \\
$\mathrm{Cd}$ & 14.53 & 13.78 & 12.66 & 13.66 \\
$\mathrm{Cu}$ & 15.30 & 14.48 & 11.84 & 13.87 \\
$\mathrm{Fe}$ & 0.88 & 0.85 & 0.80 & 0.84 \\
$\mathrm{Zn}$ & 2.22 & 2.20 & 1.80 & 2.07 \\
$\mathrm{Mn}$ & 0.47 & 0.43 & 0.38 & 0.43 \\
\hline
\end{tabular}

Table 9 Enrichment factor of soil close to Atikankan dumpsite.

\begin{tabular}{lcccc}
\hline Parameter & $\begin{array}{c}\text { Distance 0 } \\
\text { Depth 0-15cm }\end{array}$ & $\begin{array}{c}\text { Distance 10m } \\
\text { Depth 0 -15cm }\end{array}$ & $\begin{array}{c}\text { Distance 20m } \\
\text { Depth 0- 15cm }\end{array}$ & $\begin{array}{c}\text { mean } \\
\text { EF }\end{array}$ \\
\hline $\mathrm{Pb}$ & 3.23 & 2.62 & 2.62 & 2.82 \\
$\mathrm{Ni}$ & 2.46 & 2.18 & 2.09 & 2.24 \\
$\mathrm{Cr}$ & 3.71 & 3.86 & 3.57 & 3.71 \\
$\mathrm{Cd}$ & 3.00 & 3.00 & 3.00 & 3.00 \\
$\mathrm{Cu}$ & 0.76 & 0.73 & 0.64 & 0.71 \\
$\mathrm{Fe}$ & 1.00 & 1.00 & 1.00 & 1.00 \\
$\mathrm{Zn}$ & 1.37 & 1.27 & 1.21 & 1.28 \\
$\mathrm{Mn}$ & 1.11 & 1.04 & 1.00 & 1.05 \\
\hline
\end{tabular}

Table 10 Average Contamination factors (CF), geo- accumulation index (I-geo), Enrichment factor and quantification of contamination (QoC) heavy metals in soils of Atikankan dumpsite.

\begin{tabular}{lcccc}
\hline Parameter & $\begin{array}{c}\text { mean } \\
\text { Igeo }\end{array}$ & $\begin{array}{c}\text { mean } \\
\text { C/P }\end{array}$ & $\begin{array}{c}\text { (QoC) } \\
\text { \%o }\end{array}$ & $\begin{array}{c}\text { mean } \\
\text { EF }\end{array}$ \\
\hline $\mathrm{Pb}$ & 1.46 & 1.82 & 84.68 & 2.82 \\
$\mathrm{Ni}$ & 1.37 & 2.95 & 79.79 & 2.24 \\
$\mathrm{Cr}$ & 1.80 & 1.10 & 88.97 & 3.71 \\
$\mathrm{Cd}$ & 3.81 & 13.66 & 98.53 & 3.00 \\
$\mathrm{Cu}$ & 0.05 & 13.87 & 36.93 & 0.71 \\
$\mathrm{Fe}$ & 0.40 & 0.84 & 55.06 & 1.00 \\
$\mathrm{Zn}$ & 0.63 & 2.07 & 64.73 & 1.28 \\
$\mathrm{Mn}$ & 0.42 & 0.43 & 56.66 & 1.05 \\
\hline
\end{tabular}




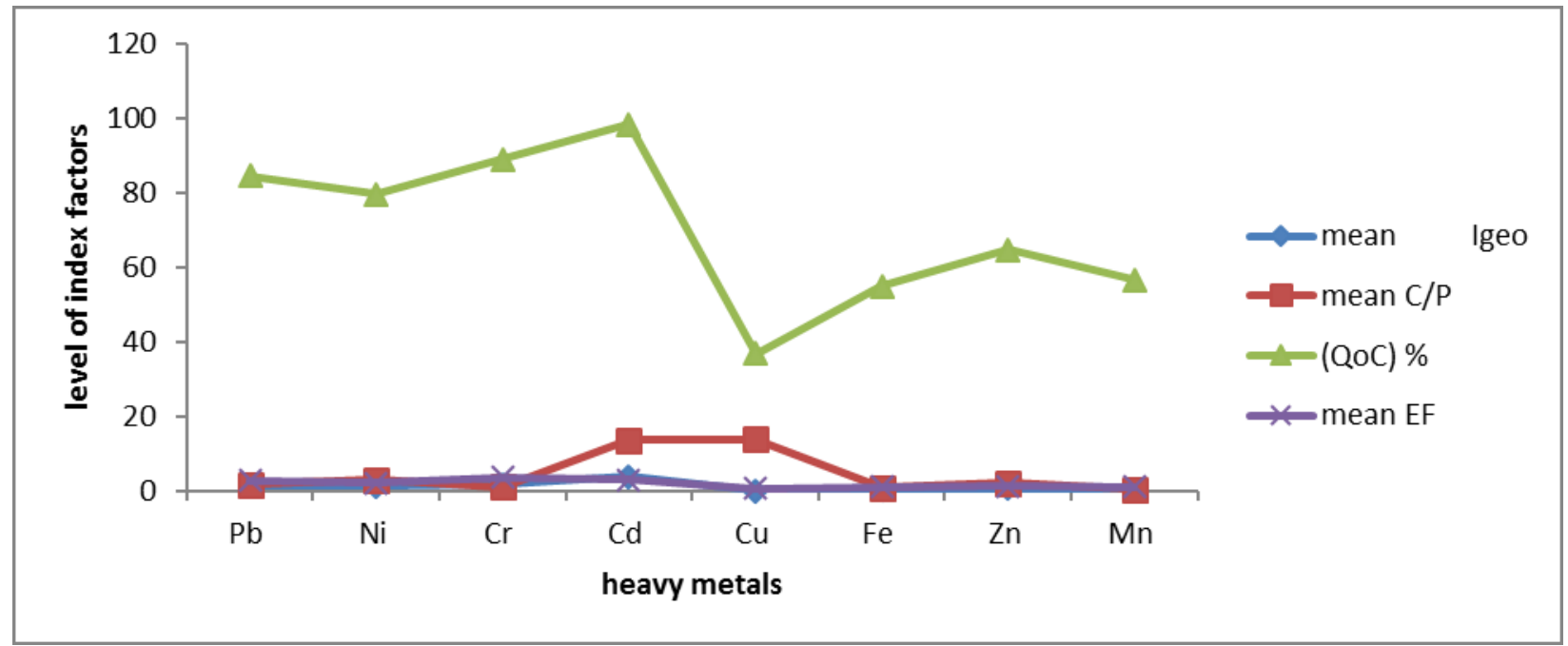

Fig.2 Pattern of metal fluctuations in the dumpsite as shown by index factors

Table 11 Concentration ranges of metals $(\mu \mathrm{g} / \mathrm{g})$ in soils and plants and critical concentrations in plants

\begin{tabular}{cccc}
\hline Parameter & $\begin{array}{c}\text { Normal range in } \\
\text { soils }\end{array}$ & $\begin{array}{c}\text { Normal range in } \\
\text { plants }\end{array}$ & $\begin{array}{c}\text { Critical plant } \\
\text { concentration }\end{array}$ \\
\hline $\mathrm{Pb}$ & $2-30$ & $0.2-20$ & $30-300$ \\
$\mathrm{Ni}$ & $2-750$ & $0.02-5$ & $10-100$ \\
$\mathrm{Cr}$ & $5-1500$ & $0-03-14$ & $5-30$ \\
$\mathrm{Cd}$ & $0.01-2$ & $0.1-2.4$ & $5-30$ \\
$\mathrm{Cu}$ & $2-250$ & $5-20$ & $20-100$ \\
$\mathrm{Fe}$ & $5000-100000$ & $40-500$ & - \\
$\mathrm{Zn}$ & $1-900$ & $1-400$ & $100-400$ \\
$\mathrm{Mn}$ & - & - & - \\
\hline
\end{tabular}

Radojevic and Bashkin (2006)

Table 12: Metal concentration (mg/kg) of crop plants from Atinkankan dumpsite

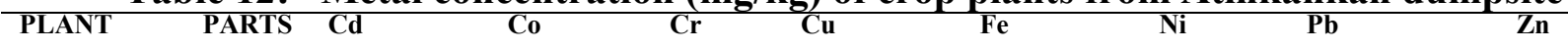
TYPE

\begin{tabular}{|c|c|c|c|c|c|c|c|c|c|}
\hline Pawpaw & Root & $6.00 \pm 0.01$ & $4.35 \pm 0.02$ & $0.03 \pm 0.01$ & $22.07 \pm 0.01$ & $72.07 \pm 0.02$ & $0.15 \pm 0.02$ & $40.13 \pm 0.02$ & $29.40 \pm 0.00$ \\
\hline \multirow[t]{2}{*}{ papaya) } & Fruits & $2.65 \pm 0.01$ & $0.97 \pm 0.01$ & BDL & $5.58 \pm 0.01$ & $79.19 \pm 0.01$ & BDL & $35.01 \pm 0.01$ & $37.25 \pm 0.01$ \\
\hline & Leaves & $3.07 \pm 0.00$ & $3.00 \pm 0.00$ & $\mathrm{BDL}$ & $11.25 \pm 0.01$ & $65.55 \pm 0.00$ & $0.06 \pm 0.01$ & $47.03 \pm 0.00$ & $34.74 \pm 0.01$ \\
\hline Cassava & Tuber & $8.03 \pm 0.01$ & $1.24 \pm 0.02$ & BDL & $14.00 \pm 0.01$ & $108.71 \pm 0.01$ & BDL & $60.50 \pm 0.01$ & $36.14 \pm 0.01$ \\
\hline esculenta) & Leaves & $1.28 \pm 0.01$ & $\mathrm{BDL}$ & BDL & $20.70 \pm 0.01$ & $88.67 \pm 0.01$ & $31.45 \pm 0.02$ & $102.11 \pm 0.02$ & $44.62 \pm 0.01$ \\
\hline Melon & Leaves & $3.85 \pm 0.02$ & $2.70 \pm 0.01$ & BDL & $3.70- \pm 0.02$ & $62.02 \pm 0.01$ & BDL & $69.145 \pm 0.02$ & $22.35 \pm 0.01$ \\
\hline \multicolumn{10}{|c|}{ (Cucumeropsis } \\
\hline \multirow[t]{2}{*}{ manni) } & Fruits & $3.09 \pm 0.01$ & $2.86 \pm 0.02$ & BDL & $6.01 \pm 0.01$ & $66.00 \pm 0.00$ & BDL & $31.02 \pm 0.00$ & $28.12 \pm 0.02$ \\
\hline & Roots & $7.15 \pm 0.01$ & $4.30 \pm 0.00$ & $0.15 \pm 0.01$ & $11.35 \pm 0.00$ & $48.04 \pm 0.01$ & BDL & $49.15 \pm 0.01$ & $35.05 \pm 0.01$ \\
\hline $\begin{array}{l}\text { Water leaf } \\
\text { (Talinum }\end{array}$ & Leaves & $8.70 \pm 0.03$ & $9.00 \pm 0.01$ & BDL & $9.20 \pm 0.02$ & $62.98 \pm 0.01$ & $0.01 \pm 0.02$ & $184.00 \pm 0.01$ & $142.00 \pm 0.02$ \\
\hline
\end{tabular}




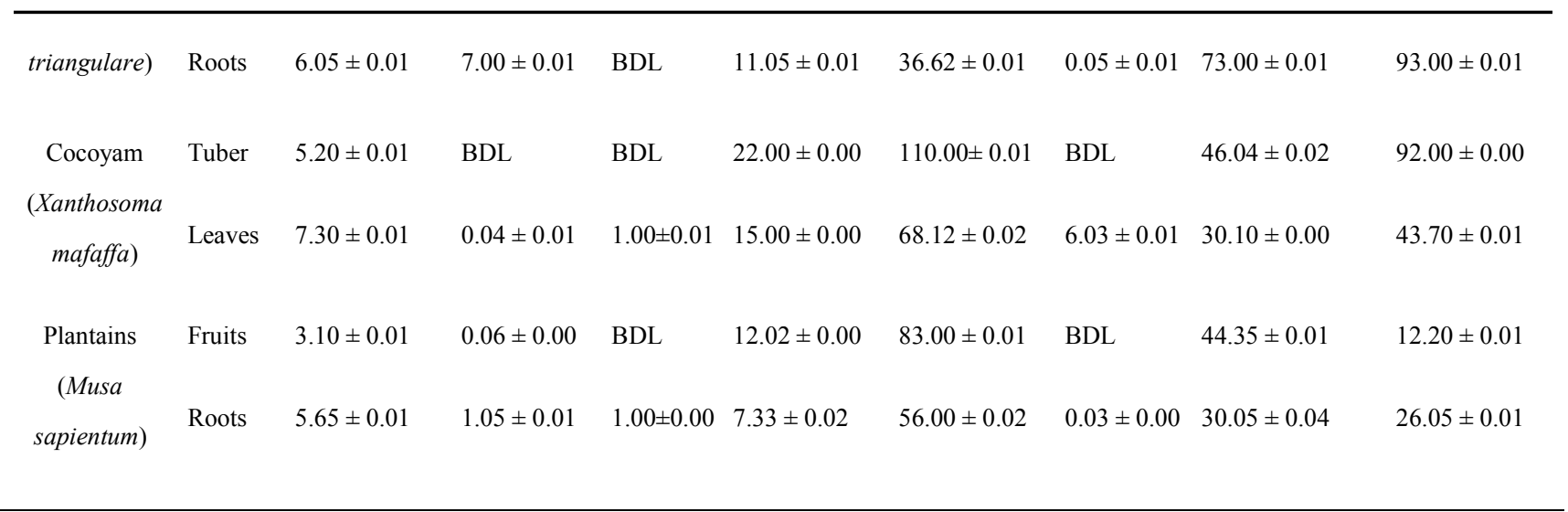

Table 13: Translocation factor of metals in crops around Atinkankan dumpsite

\begin{tabular}{|c|c|c|c|c|c|c|c|c|c|}
\hline PLANT TYPE & SAMPLES & Cd & Co & $\mathrm{Cr}$ & $\mathrm{Cu}$ & $\mathbf{F e}$ & $\mathbf{N i}$ & $\mathbf{P b}$ & Zn \\
\hline \multirow{2}{*}{$\begin{array}{c}\text { Pawpaw } \\
\text { (Carica papaya) }\end{array}$} & Site & 0.95 & 0.91 & 0 & 0.76 & 2.01 & 0.4 & 2.04 & 2.45 \\
\hline & control & 1.15 & 0.72 & 0 & 0.62 & 2.07 & 0 & 3.18 & 2.38 \\
\hline \multirow{2}{*}{$\begin{array}{c}\text { Cassava } \\
\text { (Manihot } \\
\text { esculenta) }\end{array}$} & Site & 0.09 & 0 & 0 & 1.48 & 0.82 & 0 & 1.69 & 1.24 \\
\hline & Control & 0.25 & 0 & 0 & 0.63 & 2.41 & 0 & 2.12 & 2.50 \\
\hline \multirow{2}{*}{$\begin{array}{c}\text { Melon } \\
\text { (Cucumeropsis } \\
\text { Manni) }\end{array}$} & Site & 0.97 & 1.29 & 0 & 0.86 & 2.66 & 0 & 2.04 & 1.15 \\
\hline & Control & 1.24 & 0.85 & 0 & 0.95 & 3.14 & 0 & 331 & 322 \\
\hline $\begin{array}{l}\text { Water leaf } \\
\text { (Talinum }\end{array}$ & Site & 1.44 & 1.29 & 0 & 0.83 & 1.72 & 0.2 & 2.52 & 1.53 \\
\hline triangulare) & Control & 0.45 & 0.11 & 0 & 0.31 & 1.21 & 0 & 1.55 & 1.39 \\
\hline \multirow{2}{*}{$\begin{array}{c}\text { Cocoyam } \\
\text { (Xanthosoma } \\
\text { mafaffa })\end{array}$} & Site & 1.40 & 0 & 0 & 0.68 & 0.62 & 0 & 0.65 & 0.47 \\
\hline & Control & 4.29 & 0 & 0 & 0.53 & 2.96 & 0 & 2.09 & 0.46 \\
\hline \multirow{2}{*}{$\begin{array}{c}\text { Plantains (Musa } \\
\text { sapientum) }\end{array}$} & Site & 0.55 & 0.06 & 0 & 1.64 & 1.48 & 0 & 1.48 & 0.47 \\
\hline & Control & 0.43 & 0 & 0 & 0.56 & 1.34 & 0 & 1.28 & 1.20 \\
\hline
\end{tabular}

\section{DISCUSSION}

4.1 Metal levels in soils: Soil properties determined in the present study are shown in Table 5. Soil $\mathrm{pH}$ of the landfill was neutral with higher organic matter content while the soil $\mathrm{pH}$ for control showed a slightly acidic level of 6.6 with low organic matter content. Higher organic matter content in the landfill than that of the control may be due to the presence of garden waste, food waste, paper and packaging materials, metals, glass and ash. Organic matter plays an important role in soil structure, water retention, cation exchange and in the formation of complexes. Table 6 represents the heavy metals concentrations in soils. The metal loads from the refuse dump soils were found to be higher than the background values especially for $\mathrm{Cr}, \mathrm{Fe}, \mathrm{Ni}, \mathrm{Cu}$ and $\mathrm{Zn}$. It was expected because refuse dumps receive considerable waste proportions of product packaging, waste cloths, glass and bottles, newspapers, paints, batteries, industrial dust, ash, tyre, metal cans and containers, medical waste, abandoned vehicles and insulations which are known to be sources of metals [24]. The metal loads from the refuse dump soils were, however, within the normal concentration ranges in soils (Table 11)[25]; with the exception of concentration levels of $\mathrm{Cd}, \mathrm{Cu}$ and $\mathrm{Pb}$ from Ado Ekiti refuse 
dump soils which were beyond the normal range in soils. The degree of pollution of the refuse dumps by the metals was assessed using the Geoaccumulation Index (Igeo) classification (Table 1) [26]; contamination/pollution index [16]; Enrichment factor index [18]; Pollution load index (PLI) [22]; Quantification of soil contamination (QoC) [23]. On the basis of the quantification of anthropogenic input of the heavy metals in the soils presented in Table 10, the order of contamination with individual metals is as follows: $\mathrm{Cr}>\mathrm{Mn}>\mathrm{Pb}>\mathrm{Fe}>\mathrm{Ni}>\mathrm{Zn}>\mathrm{Cd}>\mathrm{Cu}$. However, results from the different impact-assessing indices are consistent with each other as shown in fig 2. This could simply be an indication that the anthropogenic sources of the metals in the soils surrounding these waste dumpsite are of similar origin, with anthropogenic inputs in soils of the metals, generally, in a decreasing order of $\mathrm{Cd}(98.53 \%)>\mathrm{Cr}(88.97 \%)>\mathrm{Pb}(84.68 \%)>\mathrm{Ni}$ $(79.79 \%)>\operatorname{Zn}(64.73 \%)>\mathrm{Mn}(56.66 \%)>\mathrm{Fe}(55.06 \%)>\mathrm{Cu}(36.93 \%)$ as shown in Table 10.The PLI values calculated for the site was found to be polluted (PLI $>1$ ), suggesting inputs from anthropogenic sources.

4.2 Metal levels in plants: The concentration of heavy metals in crops grown around dumpsite ranged from below detection limit (BDL) to $184.0 \mathrm{mg} / \mathrm{kg}$ recorded for $\mathrm{Pb}$ in $T$. triangulare. The results also showed the highest level of Cd $(8.70 \mathrm{mg} / \mathrm{kg}), \mathrm{Co}(9.00 \mathrm{mg} / \mathrm{kg}), \mathrm{Pb}(184.0 \mathrm{mg} / \mathrm{kg})$, and $\mathrm{Zn}(142.0 \mathrm{mg} / \mathrm{kg})$ in T. triangulare; $\mathrm{Cr}(1.0 \mathrm{mg} / \mathrm{kg})$ and $\mathrm{Fe}(110.0 \mathrm{mgkg}-1)$ in $X$. mafaffa; $\mathrm{Cu}(22.07$ $\mathrm{mg} / \mathrm{kg})$ in C papaya root and $\mathrm{Ni}(31.45 \mathrm{mg} / \mathrm{kg})$ in M esculenta leaves. The variation of the various heavy metal concentrations in the plants was observed to be according to plant and metal species. They are higher in the landfill soil than in the control and this is in good agreement with earlier reports [27]. The heavy metal levels in the control were within the background level range for farming. Analytical results indicated that the concentration of $\mathrm{Cd}, \mathrm{Cu}, \mathrm{Ni}, \mathrm{Cr}, \mathrm{Zn}, \mathrm{Co}$ and $\mathrm{Pb}$ were grossly above the literature levels of a typical soil [28] and were of different variations. This might be due to the selective absorption of the metals by various crops. The elevated concentration levels detected could be hazardous to human health in the leaves of most crop samples. The transfer factor (TF), which is the ratio of the concentration of metal in the aerial portion of the plant to the total concentration in the soil, is shown in Table 13. The TF for the metals in the dumpsite were significantly different from those for control according to plant species. $\mathrm{Pb}, \mathrm{Zn}, \mathrm{Cu}$ and $\mathrm{Cd}$ had the higher TFs which are $2.52 ; 2.45 ; 1.64$ and 1.44 respectively. The highest TF value obtained for $T$. triangulare was $\mathrm{Pb}$ (2.52) and $\mathrm{Cd}$ (1.44); for C. papaya $\mathrm{Cd}$ (0.95), $\mathrm{Co}(0.91), \mathrm{Cu}(0.76), \mathrm{Ni}(0.4), \mathrm{Pb}$ (2.04) and $\mathrm{Zn} \mathrm{(2.45).} \mathrm{A} \mathrm{study} \mathrm{gave} \mathrm{a} \mathrm{generalized} \mathrm{transfer} \mathrm{coefficient} \mathrm{in} \mathrm{the} \mathrm{soil-plant} \mathrm{system} \mathrm{as:} \mathrm{Co,}$ $\mathrm{Cr}, \mathrm{Cu}$ and $\mathrm{Pb}(0.01-0.1), \mathrm{Cd}$ and $\mathrm{Zn}(1-10), \mathrm{Ni}(0.1-1)$ [29]. The TF of Co, Cr, Ni and $\mathrm{Pb}$ are above the normal range in some plants species. This study showed a $\mathrm{TF}>1$ for most metals.

\section{CONCLUSION AND RECOMMENDATIONS}

The study revealed that the landfill was polluted by $\mathrm{Cd}, \mathrm{Co}, \mathrm{Cr}, \mathrm{Cu}, \mathrm{Ni}, \mathrm{Pb}$ and $\mathrm{Zn}$ while crops were contaminated with $\mathrm{Cd}, \mathrm{Cr}, \mathrm{Cu}, \mathrm{Ni}, \mathrm{Pb}$ and $\mathrm{Zn}$. Anthropogenic release give rise to higher concentration of metals in the soils of the study area. The detected levels of total metal contamination in many of the samples were found to exceed the alert level admitted by the Nigerian and International guideline. The study clearly highlights the necessity of immediate control measures for the exceptionally severe heavy metal pollution in the study area and the soils in the area is recommended urgently for bioremediation and/or other remediation technologies such as phyto-remediation involving growing certain plants like $\mathrm{T}$. triangulare due to the high $\mathrm{TF}$ value recorded in the area to minimize the rate of contamination, and extent of future pollution problems. 


\section{References}

[1] Wild. A (1995); Soil and the Environment: An Introduction, Cambridge University press. 109165.

[2] Asomani-Boateng R., Murray H. (1999): Reusing organic solid waste in urban farming in African cities: a challenge for urban planners. In: Olanrewaju B.S. (ed.): Urban Agriculture in West Africa, Canada, 210.

[3] Woodbury P.B. (2005): Municipal solid waste composting: potential effects of heavy metals in municipal solid waste composts on plants and the environment. Available at: http://www.css.cornell.edu/compost/mswfactsheets/msw.fs5.html

[4] NI EHS National Institute of Environmental Health Services (2004): 'Waste: Landfill.' Available at: http://www.niehs.nih. gov/external/faq/landfill.htm

[5] Fatoki O.S. (2000): Trace zinc and copper concentration in road side vegetation and surface soils: a measurement of local atmospheric pollution in Alice, South Africa. International Journal of Environmental Studies, 57: 501-513.

[6] Awokunmi E.E., Asaolu S.S., Ipinmoroti K.O., (2010): Effect of leading on heavy metal concentration of soil in some dumpsites. African Journal of Environmental Science and Technology Vol. 4 (8) pp. 495 - 499.

[7] Abenchi E.S, Okunola O.J, Zubairu S.M. J, Usman A. A., Apene E - (2010): Evaluation of Heavy metals in roadside soils of major streets in Jos Metropolis, Nig. J. Environ. Chem. Ecotoxicol. 2(6):98 -102.

[8] Krishna A.K, Govil P.K (2007): Soil contamination due to heavy metals from an industrial area of Surat, Gujarat, Western India. Environ Monitoring Assess. 124:263-275.

[9] Kakulu S.E (1993): Biological monitoring of atmospheric trace metal deposition in North Eastern Nigeria. Environmental Monitoring and Assessment, 28: 137 - 143.

[10] Allison L.E (1960): Wet-combustion apparatus and procedure for organic and inorganic carbon in soil. Soil Sci. Soc. Am. Proc. pp.36 - 40.

[11] Ibitoye A.A (2006): Laboratory Manual on Basic Soil analysis. 2nd edition. Foladave Nig. 1td. Pp. 32 - 36.

[12] Awofolu O.R (2005): A survey of trace metals in the vegetation, soil and lower animals along some selected major and roads in metropolitan city of Lagos. Environmental Monitoring and Assessment, 105: 431 - 447.

[13] Oyedele D.J, Obioh I.B, Adejumo J.A, Oluwole A.F, Aina P.O, Asubiojo O.I (1995). Lead contamination of soils and vegetation in the vicinity of a lead smelter in Nigeria. The Sci. of the Total Environment, 1732: 189-195.

[14] Kothai, P.; Prathibha, P.; Saradhi, I. V.; Pandit, G. G.; Puranik, V. D., (2009): Characterization of atmospheric particulate matter using pixe technique. Int. J. Environ. Sci. Eng., 1 (1), 27 - 30

[15] Muller G., (1969); Index of geoaccumulation in sediments of the Rhine River, Journal of Geol. 2 108-118.

[16] Lacatusu R (2000): Appraising levels of soil contamination and pollution with heavy metals. In: H. J. Heineke W, Eckelmann AJ, Thomasson RJ, Jones A, Montanarella L, Buckley B (Eds.). European Soil Bureau- Research Report No. 4.Section 5(7):393 403. The European Soil Bureau, Joint Research Centre I-201020 ISPRA - Italy.

[17] Aiyesanmi, A.F. (2008): Baseline heavy metal concentrations in river sediments within Okitipupa southeast belt of the Nigerian bituminous sand field. Journal of Chemical Society of Nigeria, 33(2): 29-41. 
[18] Simex, S. A.; Helz, G. R., (1981): Regional geochemistry of trace elements in Chesapeake Bay. Environ. Geo., 3 , 315- 323

[19] Loska, K.; Wiechula, D.; Barska, B.; Cebula, E.; Chojnecka, A., (2003): Assessment of arsenic enrichment of cultivated soils in Southern Poland. Pol. J. Environ. Stud., 12 (2), 187 - 192

[20] Seshan, B. R. R.; Natesan, U.; Deepthi, K., (2010): Geochemical and statistical approach for evaluation of heavy metal pollution in core sediments in southeast coast of India. Int. J. Environ. Sci. Tech., 7 (2), 291-306

[21] Ong, M. C.; Kamaruzzaman, B. Y., (2009): An assessment of metal ( $\mathrm{Pb}$ and $\mathrm{Cu}$ ) contamination in bottom sediments from South China Sea coastal waters, Malaysia. Am. J. Appl. Sci., 6 (7), 14181423

[22] Sutherland, R. A., (2000): Bed sediment associated trace metals in an urban stream Oahu. Hawaii. Environ. Geo., 39 (6), 611-627

[23] Tomilson, D. C.; Wilson, D. J.; Harris, C. R.; Jeffrey, D. W., (1980): Problem in assessment of heavy metals in estuaries and the formation of pollution index. Helgol. Wiss. Meeresunlter, 33 (14), 566-575

[24] Woodbury P.B. (2005): Municipal solid waste composting: potential effects of heavy metals in municipal solid waste composts on plants and the environment. Available at: http://www.css. cornell.edu/compost/mswfactsheets/msw.fs5.html

[25] Radojevic M., Bashkin V.N. (2006): Practical Environmental Analysis. Royal Society of Chemistry, Cambridge, 389.

[26] Ebong G.A., Akpan M.M., Mkpenie V.N. (2008): Heavy metal contents of municipal and rural dumpsite soils and rate of accumulation by Carica papaya and Talinum triangulare in Uyo, Nigeria. E-Journal of Chemistry http://www.e-journals.net, 5: 281-290.

[27] Forstner U., Ahlf W., Calmano W. (1993): Sediment quality objectives and criteria development in Germany. Water Science and Technology, 28: 307.

[28] Madejon, P.; Murillo, J. M.; Maranon, T.; Espinar, J. L.; Cabrera, F., (2006): Accumulation of As, Cd and selected trace elements in tubers of Scirpus maritimus L. from Donana marshes (South Spain). Chemosphere, 64 (5), 742-748

[29] Kloke A, Sauerbeck DR, Vetter H (1984): Changing metal cycles and human health, (ed .J.O. Nriagu). Spinger-Verlag, Berlin. pp. 113-141. 